\title{
Historical Background of Nuclear Waste Policy Formation in Finland and Comparison with (West) Germany
}

\author{
Nagako Sato
}

\begin{abstract}
In 2001, the Finnish Parliament approved the plan for a high-level nuclear waste (HLW) repository in Finland, the first move of its kind worldwide. This article analyzes the historical background of radioactive waste policy formation in Finland, comparing it to that of (West) Germany in the Cold War context and after. Military ambitions and non-proliferation, political culture and civil society, and energy policy are considered. In Germany, reprocessing of spent nuclear fuel (SNF), which could make nuclear armament possible, was pursued until 1989 and often spurred opposition movements. Finland, in contrast, renounced reprocessing around 1980. In addition, there was a notable absence of a strong nationwide anti-nuclear movement in Finland against the backdrop of the Cold War.
\end{abstract}

Keywords nuclear power policy, radioactive waste, Cold War, anti-nuclear movement, Finland, Germany

\section{Introduction}

Finland is a highly advanced country in the field of nuclear power. Even since the Fukushima disaster in Japan on March 11, 2011, it has made no major changes to its nuclear power promotion policy. In 2001, the Finnish Parliament approved a repository plan for high-level nuclear waste (HLW) in Olkiluoto, Eurajoki municipality, in the country's southwest. This was the first such plan in the world, as countries utilizing nuclear power have encountered difficulties selecting a site for "final disposal" that would totally isolate the harmful HLW generated during the sustained operation of a nuclear power plant (NPP).

Clarifying why Finland was able to settle on a final disposal site when almost all other countries have failed to do so could contribute to resolving this issue. This issue has attracted worldwide attention and many studies have been published on this subject (e.g. OECD and NEA 2002; Kojo 2009). 
There are three main methods for HLW disposal: direct disposal, reprocessing, and transportation to other countries. Of these three, Finland has adopted the direct disposal approach. As is well known, the nuclear fuel cycle concept outlines how spent nuclear fuel (SNF) may be reprocessed after being used in NPPs; uranium and plutonium are extracted and then used as fuel again, improving energy self-sufficiency. Why then has Finland adopted direct disposal when it possesses few fossil fuel resources? What is the historical background? The analysis in this article refers to the study of Högselius (2009). As a reference case, this analysis will compare Finland to Germany, which was the first nation to decide to phase out nuclear power after the Fukushima disaster. Germany failed to pursue reprocessing, halted its initial practice of consigning waste to the United Kingdom and France, and now aims to conduct direct disposal. Nuclear waste has been a source of conflict in Germany for decades.

The difference in nuclear waste management between these two countries could already be observed at the start of the twenty-first century. Finland decided upon a final disposal site in 2001 and decided to construct a fifth NPP in 2002, the first to do so in Western Europe since the Chernobyl disaster. In contrast, Germany decided to phase out NPPs in 2000, with a set operation period of thirty-two years per reactor. In the agreement in 2000, a moratorium on the planned repository, Gorleben, was also agreed upon. In the aftermath, the exploration of Gorleben to clarify conceptual and safety issues was suspended for a minimum of three to a maximum of ten years.

Both Finland and Germany were defeated in devastating wars in the 1940s-Finland by the Soviet Union in the Winter War (1939-1940) and the Continuation War (1941-1944), and Germany by the Allies in World War II. Both nations recovered economically and are currently democratic and technologically advanced, and do not need to worry about disasters such as earthquakes that could threaten plant operation and final disposal sites. Why, then, does Finland continue to use nuclear power with an agreed-upon disposal site for high-level radioactive waste, while Germany is phasing out NPPs and no disposal site for radioactive waste has been designated? Despite its cultural and geographical proximity to Germany, Finland does not show any sign of changing its nuclear policy after Fukushima and the German phase-out decision (Hakkarainen and Fjaestad 2012; Fjaestad and Hakkarainen 2013). Disposal of harmful radioactive waste has often been a strong motivation for anti-nuclear power efforts-an "Achilles heel" for nuclear applications. Proper disposal of radioactive waste is a necessary part of the basis for nuclear applications. Therefore, this article focuses on the process of setting a radioactive waste disposal site in Finland and why no such site was selected in Germany. It also describes the historical background: why direct disposal was chosen in Finland while reprocessing was sought and abandoned in Germany, with a change to direct disposal. 


\section{Definition of Terms and Analytical Framework}

\section{Definition of Terms}

Beyond the International Atomic Energy Agency (IAEA)'s general framework concerning "radioactive waste," the actual detailed definition of types of waste and protocols for dealing with waste are controlled at the national level and there are various standards. "High-level radioactive waste" (HLW) is roughly classified as follows: in countries that adopt "direct disposal" to dispose of SNF, that SNF is classified as HLW; on the other hand, in countries that reprocess uranium and plutonium from SNF, the remaining waste is classified as HLW. Since Finland has adopted direct disposal, its SNF is classified as HLW. On the other hand, given that Germany entrusted its reprocessing to the United Kingdom and France through 2005 and it is presently re-receiving the waste after reprocessing, the nation possesses and has to deal with both SNF and the waste remaining after reprocessing. In this article, the term "HLW" is applied in the cases of both countries for nuclear waste that emits particularly strong radiation, regardless of the method by which it is handled. In addition, only nuclear waste from NPPs is covered here.

Currently, the best way to handle HLW is considered to be deep burial after cooling, where it will be completely isolated from the human environment for thousands to tens of thousands of years until it is detoxified. In practice, the HLW dealt with here is spent nuclear fuel in Finland and both SNF and waste liquid after reprocessing in Germany; these are strictly different, but can be treated in common here as both need a place to be stored for several tens of thousands of years, deep in the earth, generally speaking in the home country; and people generally tend to be repelled because of the danger. Also, using the term "HLW" can help abstract the problem and smooth out the discussion without getting caught up on presently irrelevant details.

\section{Analytical Framework}

Högselius (2009) suggests five factors by which we can analyze the reasons that SNF disposal methods differ between countries: military ambition, technical culture, political culture and civil society, geological situation, and energy policies. However, as he stated himself, these are meant to cover global policy and need adjustment. For this reason, this article focuses on military ambition, political culture and civil society, and energy policy. Technical culture is also an interesting theme, but it cannot be addressed here because of the importance of diplomacy for both defeated countries, the international political situation effected by the Cold War, and length constraints on the present article. In addition, since both countries basically have stable rock underneath, geological conditions need not be addressed here.

In the following section, the general energy policy situations are discussed; 
after that, the foreign policy and domestic politics are compared.

\section{Comparative Analysis of the Two Countries}

\section{General Energy Policy Situation}

Finland has 5.379 million people in 338 thousand square kilometers of land and few fossil fuel resources. Because of rapid industrialization and urbanization after World War II, it has been said that Finland transformed from an agricultural to an industrialized country from the 1950s to the 1970s. In particular, industrialization took the form of development in the field of forestry. Pulp factories required considerable amounts of energy and this encouraged the use of water resources for energy production and the construction of NPPs (Konttinen 1999, 22).

There are two units each operating in Loviisa and Olkiluoto-altogether four nuclear reactors that provide about 30 percent of the nation's total electricity. Furthermore, the European Pressurized Water Reactor (EPR), which will be the fifth domestic reactor in Finland, is under construction in Olkiluoto. In addition, another is planned for the Hanhikivi Peninsula in the municipality of Pyhäjoki. It must also be added that the former Soviet Union NPPs at Loviisa have been improved and are still operating.

In the Finnish Parliament, the Green League (Vihreä liitto) is the only party against the expansion of nuclear power. Many voters tend not to consider nuclear power to be an important issue. Only minor problems concerning nuclear technology have occurred so far in Finland. However, after the Fukushima disaster, demonstrations with hundreds of participants occurred, particularly in the capital (Libermann 2011). In the end, the Fukushima accident did not receive much political attention, even though it happened during the Finnish election campaign. With regard to Germany's decision to quit nuclear power, there were concerns about the potential impact of rising electricity prices in the European market and their implications for Finland. Besides, nuclear power could possibly be replaced by fossil fuels, impacting negatively the European goal of reducing carbon dioxide emissions to counter climate change (Hakkarainen and Fjaestad 2012, 237-240; Fjaestad and Hakkarainen 2013, 3-4). Most Finns trust that their own nuclear power plants are totally safe (Libermann 2011).

Finland relies on coal and gas imports for most of its energy. Approximately 66 percent of coal is imported from Russia, and the remainder comes from Poland; all gas comes from Russia. Approximately 7 billion euros a year is paid for imports that account for two-thirds of total energy, and two-thirds of these imports come from Russia (World Nuclear Association 2018b). Finland has sought to become energy self-sufficient in order to stop relying on imports from the Soviet Union/Russia. According to the government's energy strategy, nuclear 
energy is valued as a source that does not emit greenhouse gases.

Germany holds 80.79 million people in 357 thousand square kilometers of land. It has substantial domestic coal mining operations, but nuclear power has been promoted since the oil crises of the 1970s. After the Chernobyl disaster in 1986, momentum for phasing out nuclear power increased and a transition to natural energy was promoted. In contrast to Finland, the Fukushima disaster had a big impact on Germany. Before the disaster, the German government already had a plan to halt the nuclear power phase out. ${ }^{1}$ However, after the disaster, the focus shifted to the "Ethics Committee for Safe Energy Supply," a discussion forum between nuclear supporters and opponents. Based on its outcomes, the government decided upon a new policy to immediately shut down all seventeen NPPs by 2022. In the committee report, it was pointed out that the question of the costs of phasing out nuclear energy also need to be compared to the costs of coping with a nuclear accident such as that currently occurring in Japan: all of these costs would exceed the anticipated costs that would be attributable to Germany's energy transition (Ethik-Kommission Sichere Energieversorgung 2011, 24). In the local parliamentary (Landtag) elections in 2011, the Green Party advanced, and in the state (Land) of Baden-Württemberg, a Green politician took office as minister-president (Ministerpräsident) for the first time. At that time, there were anti-nuclear protests, the size of which is said to have ranged from the tens of thousands up to 250,000 participants (Süddeutsche Zeitung 2011).

Before the disaster, Germany had obtained about 25 percent of its total electricity from its seventeen NPPs. Currently, about 12 percent of its electricity is supplied by seven reactors (World Nuclear Association 2018a). At present, there are few politicians advocating for nuclear power in Germany. About 40 percent of its energy sources are coal (about 23 percent is brown coal), 13 percent natural gas, 1 percent petroleum products, and 30 percent renewable energy (Statistisches Bundesamt 2017). Approximately one-third of the oil and natural gas is imported from Russia (Zeit Online 2014), but Germany is not as dependent on that one country as Finland is.

\section{Military Ambitions and Non-Proliferation}

“A first important factor that has influenced countries' SNF strategies has historically been their varying ambitions with respect to nuclear weapons. Most nuclear weapons countries have seen it as a necessity to build up a competence within the field of reprocessing, since reprocessing is the only known way to produce plutonium" (Högselius 2009, 256).

After the atomic bomb was dropped on Japan in 1945, the Soviet Union conducted nuclear tests in 1949, followed by Britain in 1952, France in 1960, and China in 1964. In 1968, the Treaty on the Non-Proliferation of Nuclear Weapons (NPT) was signed to prevent countries other than these five nuclear weapon states from developing or possessing nuclear weapons. These countries decided 
not to support the development of nuclear weapons in countries that did not then have nuclear weapons, while countries that did not possess nuclear weapons and joined the treaty agreed not to produce nuclear weapons. In return, they were guaranteed the right to use nuclear energy for peaceful purposes.

In this respect, Germany and Finland do not possess their own nuclear weapons (at least publicly), but there are slight differences in the circumstances surrounding reprocessing that may be related to nuclear proliferation.

The Finnish people were consistently concerned about Soviet encroachment against a historical background. The Soviet Union attacked and occupied many small countries. Since Finland shares a border with this country, it was also exposed to the threat of Soviet invasion.

After Finland was defeated by the Soviet Union in the Winter War of 19391940 and the Continuation War of 1941-1944, a severe truce agreement was signed in September 1944. The Finnish people were in dire need at the time, but in order not to worsen its relationship with the Soviet Union, Finland declined the U.S. reconstruction assistance plan, the "Marshall Plan," announced in 1947.

In April 1948, Finland and the Soviet Union concluded the Agreement of Friendship, Cooperation, and Mutual Assistance (the "YYA Treaty"). In the YYA Treaty, it is stipulated that if Finland is targeted as a transit country for an invasion of the Soviet Union, Finland will fight to repel the invaders.

When Finland was invaded by the Soviet Union, it received little security aid from other countries. Against this historical backdrop, Finnish president Juho Kusti Paasikivi (in office 1946-1956) adopted a neutral policy based on a friendly relationship with the Soviet Union, and his successor, Urho Kaleva Kekkonen (1956-1982), did the same.

Because of the YYA Treaty, however, Finland was exposed to the danger of having its internal affairs meddled in by the Soviet Union. ${ }^{2}$ Finland did not join the European Community (EC), and became only a partial member of the European Free Trade Association (EFTA) in 1961; its formal accession was not until 1986. Following the Treaty of Peace with Finland signed between the Allied countries, including the Soviet Union and Finland in 1947, armament in Finland was limited, and the possession of nuclear weapons, missiles, and submarines was prohibited. In 1963, the Nordic Non-Nuclear Weapon-Free Zone (NWFZ) agreement was proposed by President Kekkonen against European military buildup; it was revived in the 1980s (Momose 1989). It presented the Nordic states' desire to avoid inclusion in a Cold War nuclear exchange. Finland had no nuclear weapons, so there was no disagreement in Finland over signing the NPT among political parties and interest groups (van Dassen 1998, 19-20).

Of course, Finland could not behave freely regarding the civilian use of nuclear power. The first nuclear technology in Finland was provided by the Soviet Union under pressure, with subsequent technology provided by Sweden (Michelsen 2013). Initially, reprocessing was also seen as an option in Finland. 
However, in 1974, India shocked the world by testing a nuclear explosive made with plutonium separated with reprocessing technology. There were concerns that nuclear terrorism could become a reality through reprocessing (von Hippel 2001). After that, the United States began to revise its own nuclear policy, abandoned its own nuclear fuel cycle development using reprocessing technology and fast breeder reactor technology, and strongly called upon other countries to do the same. As Cold War tensions increased, the Soviet Union was keen to prevent radioactive waste from falling into the hands of NATO countries and vice versa (Suominen 1999, 29). In addition, it became clear that reprocessing was considerably more expensive than anticipated. Apart from commissioning the disposal of SNF from NPPs in Loviisa by sending it to the Soviet Union for processing, Finland gave up on the option of reprocessing, and starting in 1980 adopted direct disposal in-country. It can be pointed out that there were enough reasons why Finland did not choose reprocessing, because it was a sensitive issue in the Cold War and would occur considerable costs.

After World War II, unlike Finland, Germany was divided into four zones, respectively occupied by the United States, the United Kingdom, France, and the Soviet Union. After the establishment of East Germany in 1949, diplomacy which emphasized close relations with the United States was conducted by West German Chancellor Adenauer. He was also strongly anti-Soviet and anticommunist (Itabashi 2014, 63-71). Resistance to the reconstruction of West Germany was deeply rooted in European sentiment, but economic and military restoration of West Germany was nevertheless required because of the priority given to the containment of the Soviet Union in the Cold War.

In view of international circumstances such as the North Korean invasion of South Korea in 1950 igniting the Korean War and the Soviet Union threats to use nuclear weapons against the United Kingdom during the Suez crisis in 1956, Europe needed West German strength for its defense, and the development of nuclear weapons was discussed in West Germany (Schwartz 1983, 3561). Nuclear physicists recommended against German nuclear weapons, but controversy about reprocessing and nuclear armament continued. Germany was at the forefront of the Cold War conflict owing to geographical conditions, and many politicians in the CDU/CSU (Christlich Demokratische Union Deutschlands / Christlich-Soziale Union in Bayern e. V.) expressed strong opposition to the NPT (Tsuzaki 2019, 187-190; Der Spiegel 1967). The rejection of reprocessing technology and fast breeder reactor technology in the United States boosted the protests in West Germany against the plan to construct a breeder reactor at Kalkar and a reprocessing facility in Gorleben (Radkau and Hahn 2013, 304). However, reprocessing was not abandoned, although doubts about the economics of it increased. When U.S.-Soviet relations began to become tense again around the end of the 1970s, the anti-nuclear movement in West Germany became the largest in Western Europe (Takemoto 2017, 190-202). The 
anti-nuclear and peace movements were linked (Radkau and Hahn 2013, 306307). Although protests temporarily calmed down, the largest protests yet were observed after the Chernobyl disaster, against the background of a rise in antinuclear public opinion and under the suspicion of diversion of nuclear waste to nuclear weapons after reprocessing (Radkau 2011, 371). Ultimately, the dream of reprocessing ended in 1989 for economic reasons. Summarizing the above, West Germany gave up reprocessing because the relationship with nuclear weapons was questioned, the anti-nuclear movement grew after Chernobyl, and the cost of reprocessing rose.

Today neither country has its own nuclear weapons. However, partly since West Germany had pursued reprocessing, which could lead to nuclear weapons, without responding to U.S. calls to give up this practice, public opinion turned against nuclear armament, especially after the Chernobyl disaster. On the other hand, since Finland abandoned reprocessing around 1980, military use of nuclear power was not as controversial as in Germany; as a result, there were no strong ties in Finland between the peace movement and anti-nuclear movement as there were in Germany. ${ }^{3}$

\section{Political Culture and Civil Society}

The type of political system is a factor that has played a major role in countries' divergent choices on SNF strategies; in particular, strong differences are evident between democratic and non-democratic countries. It is obvious that countries with authoritarian and semi-authoritarian governance structures, such as Russia, China, and North Korea, have found it easier to sustain reprocessing-oriented strategies in times when these have been subject to heavy criticism in other parts of the world (Högselius 2009, 259).

In the Cold War period, Finland exported its SNF to the Soviet Union. "In principle, this was a form of political coercion... Two Soviet-designed reactors in Finland were also part of this SNF regime up to 1996... The principle of exporting SNF to the Soviet Union contributed strongly to an East European nuclear power culture in which SNF was never a major issue" (ibid.).

Two perspectives should be proposed here. The first is that Finland and East Germany were each part of the SNF regime. The second is that the political environment changed because of the end of the Cold War and accession to the European Community (EC)/European Union (EU).

In the beginning, Finland was optimistic about the nuclear waste problem because of its low population density and adequate space for waste disposal (Lidskog and Litmanen 1997, 69; Kojo 2009, 163). In addition, as mentioned above, Finland could entrust the disposal of SNF from the NPP in Loviisa to the Soviet Union, which introduced that facility. Therefore, Finland did not need to take about half of SNF into consideration.

In the early 1980s when Cold War tensions increased further, the anti- 
nuclear and peace movement progressed in Europe with a critical eye on the military and civilian use of nuclear technology. In this context, Finland was in a rare situation, with domestic NPPs from both the East and West. Many activists in the anti-nuclear peace movement hardly opposed the civilian use of nuclear technology, and many members of the peace movement were supporters of the Soviet Union. In Finland there have been three major influential peace groups. The oldest peace movement, the Peace Union of Finland (Suomen Rauhanliitto), has been a traditional Christian-liberal pacifism organization, emphasizing the importance of the role of the United Nations. The Peace Committee (Rauhanpuolustajat), a peace organization founded in 1949, was closely related to the Finnish Communists, and all of their actions were calculated from the point of having a good relationship between Finland and the Soviet Union. The other peace group, The Committee of 100 (Sadankomitealiitto), was founded in 1963 based on the real fear of a coming nuclear attack. Like the Peace Committee, it did not oppose civilian use of nuclear technology. In addition, the anti-nuclear peace movement was the subject of criticism by some politicians, who indicated that it was contrary to Finland's public foreign policy and good relations between Finland and the Soviet Union (Litmanen 1998, 3-8). Politicians of the right, center, and left indirectly but almost universally condemned the protest movement. ${ }^{4}$ Ultimately, the anti-nuclear weapons movement in Finland did not become a strong force against civil use of nuclear energy.

After the Chernobyl disaster, however, Finland became strongly aware for the first time of the risk of utilizing nuclear power (Suhonen and Virtanen 1988, 71). After the disaster, a Decision in Principle (DiP) concerning the construction of a new NPP was withdrawn. ${ }^{5}$ According to opinion polls, however, over 70 percent of Finns felt the information was inadequate. It was said that there was a policy to intentionally avoid discussing the controversial approach on radio and TV (Findahl 1992, 135). In Sweden, all newspaper editorials seemed to support the government's decision to close the nuclear plants, but in Finland, only 40 percent of newspaper editorials were critical of nuclear power (ibid., 142). Remarks that could arouse doubt about the NPP infrastructure's connection with the Soviet Union rarely appeared in Finnish media; Finland's information policy was instead featured as a problem (Rautio 2011, 10). Even so, the nuclear industry stagnated. The construction of the fifth reactor in the country did not occur as intended in September 1993 because of opposition in Parliament. However, around 1994, a new argument by nuclear advocates began to emerge that nuclear power was the only viable source of energy as a measure against climate change, especially compared to fossil fuels (Litmanen and Kojo 2011, 178).

After the collapse of the Soviet Union, the transport of SNF from the NPP in Loviisa in Finland to Russia stopped. In addition to the dangers of railway transport accidents and terrorism, environmental pollution and the health hazards it presented to the neighboring residents of the Mayak reprocessing 
facility near Chelyabinsk in Russia were condemned (Simes 1999, 259-261). International public opinion that nuclear waste should be disposed of in the country that generated it became louder, and the nuclear waste policy in Finland needed to be revised ahead of accession to the EC/EU (Sandberg 1999, 50-51). In 1994, the Finnish National Parliament revised the Atomic Energy Act to prohibit the export and import of HLW, deciding to dispose of it in Finland itself. Therefore, transportation of SNF to Russia ended in 1996. Thus, the international situation around Finland changed drastically. The siting of a repository also progressed rapidly. Until then, the repository siting plan was abandoned in some areas of Finland (Kojo 2006). In 1994, Eurajoki municipality withdrew an agreement that nuclear waste would not be disposed of there, and, in 1998, the "Olkiluoto Vision" was approved, including positive affirmation of the construction of a NPP in the municipality as well as a final disposal site for SNF (Kojo 2009, 176, 180).

Meanwhile, in West Germany, the book The Nuclear State by Robert Jungk was published in 1977 (Jungk 1977); people took notice of the opinion that nuclear power is a threat to democracy. In West Germany, with its Nazi past and strong emphasis on democracy, the book caused a sensation. Furthermore, with the rise of environmental awareness, nuclear power and environmental protection also became important issues. Around 1980 as Cold War tensions increased, a large-scale movement took place, the anti-nuclear movement increased drastically after the Chernobyl disaster, and reprocessing was abandoned in 1989, as mentioned above. After that, reprocessing was entrusted to France, but once HLW was transported to Germany after being reprocessed, it instigated the antinuclear movement again.

Of course, before the reunification of East and West Germany, East Germany had NPPs introduced from the former Soviet Union and there was a SNF regime that was similar to that of Finland. However, after "unity," when East Germany essentially joined West Germany, the "Western" national system basically took over. At that time, the population of East Germany was about one-quarter that of West Germany, East Germany's economy fell into financial hardship, environmental pollution was remarkable, and NPPs in East Germany were shut down sequentially for not meeting West Germany's safety standards. The nuclear policy of unified Germany as well as its values were primarily those of West Germany.

\section{Conclusion}

In this article, referring to the study by Högselius (2009), the historical background of Finnish radioactive waste disposal policy formation was analyzed through comparison with that of Germany. 
In West Germany after World War II, a U.S.-oriented foreign policy was adopted which was anti-Soviet and anti-communist. During the Cold War, the need for nuclear armament in West Germany for the defense of Europe was asserted by many major politicians and public disagreement over the NPT occurred. West Germany did not abandon reprocessing, a practice that was alleged to potentially lead to nuclear proliferation, until 1989. Meanwhile, however, the United States' refusal to use reprocessing technology or fast breeder reactor technology encouraged the West German opposition campaign, and a large-scale anti-nuclear peace movement developed in Europe around the end of the 1970s. After the Chernobyl disaster, there were large protests that focused on reprocessing facilities, and since the 1990s, anti-nuclear movements against radioactive waste left over from reprocessing in the United Kingdom and France have been frequently reported.

Meanwhile, in Finland, under the strong but not definitive influence of the Soviet Union, the idea of the Nordic NWFZ was proposed, the choice to reprocess was abandoned as Cold War tensions increased around 1980, and direct disposal was adopted as the basic policy. When the anti-nuclear peace movement in Europe was at its largest, the movement in Finland was divided because Finland possessed NPPs from both the East and the West. After the Chernobyl disaster, the risk of nuclear power was strongly recognized by many Finnish people for the first time; however, domestic criticism was not directed towards NPPs but rather toward the domestic information policy. After the collapse of the Soviet Union, the international situation surrounding Finland changed drastically and its problem-solving process regarding the final disposal of nuclear waste progressed rapidly. The absence of a strong nationwide anti-nuclear movement in Finland, against the backdrop of the Cold War, is one reason why Finland was the first nation in the world to decide upon a final disposal site plan. Other helpful factors for the adoption of direct disposal was that the amount of radioactive waste for which Finland should have taken responsibility was relatively low because about half of it had been commissioned to the former Soviet Union, direct disposal was less expensive than reprocessing, and reprocessing and radioactive waste were supervised by the major powers during the Cold War.

This study has concluded that the East-West confrontation during the Cold War affected the formation of radioactive waste disposal policy in Finland compared with that of (West) Germany. However, the considerations addressed in this article are only some of a multitude of complex and diverse factors.

In particular, in future research, the Finnish and German "technical culture" mentioned by Högselius (ibid.) should be analyzed. Even though a site for the repository of radioactive waste has been decided, this does not mean that it is a permanent solution. Humankind must coexist with its nuclear legacy permanently, so it is desirable to research the effects of Finland's decision continuously. 


\section{Notes}

1. In 2000, the coalition government of the SPD (Sozialdemokratische Partei Deutschlands) and the Green Party reached an agreement with a power company to phase out nuclear power. However, in 2010, the coalition government comprised of the CDU/CSU (Christlich Demokratische Union Deutschlands / Christlich-Soziale Union in Bayern e. V.) and the FDP (Freie Demokratische Partei) extended the operation of NPPs by an average of twelve years, despite large scale of protests in Germany. The details of this development have been omitted due to space considerations.

2. As symbolic incidents in the interference in Finnish affairs by the Soviet Union, the "Night Frost Crisis" in 1957 and the "Note Crisis" in 1962 should be pointed out. With regard to these, "Finlandization," and politics, see Momose (1990).

3. In Finland, the construction plan for reprocessing facilities did not actually progress, so it is not possible to compare how much influence views of reprocessing had on social attitudes between the Finnish and West German cases. However, due to the abandonment of reprocessing, it can be said that the related incentive to stimulate people's fear of nuclear armament was absent in Finland.

4. Email interview with Böök Mikael, a Finnish peace activist (August 29, 2017).

5. The Decision in Principle ( $\mathrm{DiP}$ ) is Finland's unique procedure wherein the government judges whether a plan benefits society as a whole, after which the plan is approved by the National Parliament.

\section{Acknowledgements}

This work was supported by KAKENHI (15H03257/16K01984) and by a research grant from the Murata Science Foundation (2016). The author has previously published a paper addressing similar questions in the Japanese Journal of Northern European Studies (2017).

\section{References}

Der Spiegel. 1967. "Atom-Sperrvertrag / Schlag der Trommeln" [Treaty on the NonProliferation of Nuclear Weapons / Playing drums]. February 27, 10: 17-30. https:// www.spiegel.de/spiegel/print/d-46394430.html (accessed April 10, 2019).

Ethik-Kommission Sichere Energieversorgung. 2011. Deutschlands Energiewende - Ein Gemeinschaftswerk für die Zukunft [Germany's Energychange - A Joint Venture for the Future]. May. https://www.nachhaltigkeitsrat.de/wp-content/uploads/ migration/documents/2011-05-30-abschlussbericht-ethikkommission_property_ publicationFile.pdf (accessed April 7, 2019).

Findahl, Olle. 1992. "Chernobyl - The Scandinavian case." In Television and Nuclear Power: Making the Public Mind, ed. J. M. Wober, 125-143. Norwood, NJ: Ablex Publishing Corp.

Fjaestad, Maja, and Petri Hakkarainen. 2013. "Sweden, Finland and the German 
Energiewende." Friedrich Ebert Stiftung. http://library.fes.de/pdf-files/id/10163.pdf. (accessed April 6, 2019).

Hakkarainen, Petri, and Maja Fjaestad. 2012. "Diverging Nuclear Energy Paths: Swedish and Finnish Reactions to the Energiewende." Renewable Energy Law and Policy Review 3 (4): 234-244.

Högselius, Per. 2009. “Spent Nuclear Fuel Policies in Historical Perspective." Energy Policy 37 (1): 254-263.

Itabashi, Takumi. 2014. Adenauer (Japanisch). Tokyo: Chukosinsho.

Jungk, Robert. 1977. Der Atom-Staat: vom Fortschritt in die Unmenschlichkeit [The Nuclear State: From Progress to Inhumanity]. München: Kindler.

Kojo, Matti. 2006. “CARL Country Report Finland." http://www.carl-research.org/ docs/20060614144716PSUZ.pdf (accessed March 15, 2017).

Kojo, Matti. 2009. "The Strategy of Site Selection for the Spend Nuclear Fuel Repository in Finland." In The Renewal of Nuclear Power in Finland, eds. M. Kojo and T. Litmanen, 161-191. London: Palgrave Macmillan.

Konttinen, Esa. 1999. "Four Waves of Environmental Protest." In All Shades of Green, eds. E. Konttinen, T. Litmanen, M. Nieminen and M. Ylönen, 20-46. Jyväskylä: University of Jyväskylä.

Libermann, Rebecca. 2011. "Few Fukushima Fears for the Finns." This is FINLAND, Finland Promotion Board. http://213214149112.edelkey.net/Public/default.aspx?cont entid=221174\&nodeid $=41800 \&$ culture $=$ en-US (accessed November 28, 2018).

Lidskog, Rolf, and Tapio Litmanen. 1997. "The Social Shaping of Radwaste Management." Current Sociology 45 (3): 59-79.

Litmanen, Tapio. 1998. "International Anti-Nuclear Movements in Finland, France and the United States." Peace Research 30 (4): 1-19.

Litmanen, Tapio, and Matti Kojo. 2011. "Not Excluding Nuclear Power: The Dynamics and Stability of Nuclear Power Policy Arrangements in Finland." Journal of Integrative Environmental Sciences 8 (3): 171-194.

Michelsen, Karl-Erik. 2013. “An Uneasy Alliance: Negotiating Transnational Infrastructures at the Finnish-Soviet Border." In The Making of Europe's Critical Infrastructure: Common Connections and Shared Vulnerabilities, eds. P. Högselius, A. Hommels, A. Kaijser, and E. van der Vleuten, 108-130. London: Palgrave Macmillan.

Momose, Hiroshi. 1989. "Kakehashi to shiteno syōkoku gaikō" [Small Country’s Diplomacy as a Bridge]. Sekai 523: 293-301.

Momose, Hiroshi. 1990. "Finland ka'-ron no kiseki oboegaki” [Memorandum about the Development of Finlandization Theory]. Kaigaijijo 38 (1): 86-102.

OECD (Organisation for Economic Co-operation and Development), and NEA (Nuclear Energy Agency). 2002. "Stepwise Decision Making in Finland for the Disposal of Spent Nuclear Fuel.” Workshop Proceedings, Turku, Finland, November 15-16, 2001. https://www.oecd-nea.org/rwm/pubs/2002/3616-stepwise-decision-making.pdf (accessed April 14, 2019).

Radkau, Joachim. 2011. Die Ära der Ökologie [The Era of Ecology]. München: C.H. Beck.

Radkau, Joachim, and Lothar Hahn. 2013. Aufstieg und Fall der deutschen Atomwirtschaft [The Rise and Fall of the German Atomic Industry]. München: oekom verlag.

Rautio, Pekka. 2011. “Ei havaittavaa haittaa...' - Tshernobylin ydinvoimala onnettomuuden tiedottamisen politisoituminen Suomessa" ['No Noticeable Damage...' - The 
Politicization of Information about the Chernobyl Nuclear Accident in Finland]. Media \& viestintä 34 (2): 4-19.

Sandberg, Jorma. 1999. "Päättäkö eduskunta geologisesta loppusijoituksesta jo vuonna 1994?” [Did the Parliament Decide on Geological Disposal Already in 1994?]. In Ydinjäte käsissämme. Suomen ydinjätehuolto ja yhteiskunta [Nuclear Waste in Our Hands: Finnish Nuclear Waste Management and Finnish Society], eds. T. Litmanen, P. Hokkanen, and M. Kojo, 43-64. Jyväskylä: Jyväskylän yliopisto.

Schwartz, David N. 1983. NATO's Nuclear Dilemmas. Washington, D. C.: Brookings Institution.

Simes, Iida. 1999. "Ydinjätehuollon harhapolut. Suomen luonnonsuojeluliiton näkemyksiä ydinjätepolitiikasta" [The Wrong Track in Nuclear Waste Management. The Opinions of the Finnish Environmental Protection Association on Nuclear Waste Politics]." In Ydinjäte käsissämme. Suomen ydinjätehuolto ja yhteiskunta [Nuclear Waste in Our Hands: Finnish Nuclear Waste Management and Finnish Society], eds. T. Litmanen, P. Hokkanen, and M. Kojo, 258-265. Jyväskylä: Jyväskylän yliopisto.

Statistisches Bundesamt. 2017. https://www.destatis.de/DE/Themen/BranchenUnternehmen/Energie/Erzeugung/Tabellen/bruttostromerzeugung.html (accessed April 1, 2019).

Suhonen, Pertti, and Hannu Virtanen. 1988. "How the Finns Reacted to the Chernobyl Nuclear Accident." In Mass Media and Public Opinion: Report of the Fifth SovietFinnish Seminar, ed. J. Jyrkiäinen, 68-81. Tampere: University of Tampere.

Suominen, Petteri. 1999. "Ydinjätepolitiikan muotoutuminen suomessa" [Formation of the Nuclear Waste Policy in Finland]. In Ydinjäte käsissämme: Suomen ydinjätehuolto ja suomalainen yhteiskunta [Nuclear Waste in Our Hands: Finnish Nuclear Waste Management and Finnish Society], eds. T. Litmanen, P. Hokkanen, and M. Kojo, 1542. Jyväskylä: Jyväskylän yliopisto.

Süddeutsche Zeitung. 2011. "Anti-Atom-Bewegung mobilisiert 250.000 Menschen" [Anti-Nuclear Movement Mobilizes 250,000 People]. April 27. https://www. sueddeutsche.de/politik/bundesweite-proteste-anti-atom-bewegung-mobilisiertzehntausende-1.1077642 (accessed April 17, 2019).

Takemoto, Makiko. 2017. Doitsu no Heiwasyugi to Heiwa undō [Pacifism and Peace Movement in Germany]. Kyoto: Hōritsubunkasya.

Tsuzaki, Naoto. 2019. Doitsu no Kaku hoyūron [German Nuclear Possession Problem]. Kyoto: Shōwadō.

van Dassen, Lars. 1998. "Finland and Nuclear Non-Proliferation: The Evolution and Cultivation of a Norm." Statens kärnkraftinspektion (SKI) Report 98:15, SKI, Stockholm.

von Hippel, Frank N. 2001. "Plutonium and Reprocessing of Spent Nuclear Fuel." Science 293 (5539): 2397-2398.

World Nuclear Association. 2018a. "Nuclear Power in Germany." http://www.worldnuclear.org/information-library/country-profiles/countries-g-n/germany.aspx (accessed November 28, 2018).

World Nuclear Association. 2018b. "Nuclear Power in Finland." http://www.world-nuclear. org/information-library/country-profiles/countries-a-f/finland.aspx (accessed November 28, 2018).

Zeit Online. 2014. "Ohne Russland geht es nicht” [It Is Not Possible Without Russia]. 
December 8. http://www.zeit.de/politik/deutschland/2014-12/energie-deutschlandrussland-abhaengig (accessed November 28, 2018).

Nagako Sato is currently a Visiting Researcher at the Osaka School of International Public Policy (OSIPP), Osaka University, and is lecturing at Kagawa University and Shūjitsu University. She received her Ph.D. in International Public Policy from Osaka University. She has published research papers exploring topics such as political culture, environmental movements, and politics of nuclear energy and nuclear waste.

Submitted: November 29, 2018; Revised: April 29, 2019; Accepted: May 6, 2019 
